\title{
Effect of Vermicompost, Rock Phosphate, PSB and Different Bio-products on Yield and Economics of Groundnut (Arachis hypogea L.)
}

\author{
Ashwini R. Chavan*, S. A. Chavan, Aparna M. Yadav and V. G. Chavan \\ Department of Agronomy, College of Agriculture, Dr. Balasaheb Sawant Konkan Krishi \\ Vidyapeeth, Dapoli- 415712 Maharashtra, India \\ *Corresponding author
}

\section{A B S T R A C T}

\section{Keywords}

Vermicompost, Rock phosphate, PSB, Cow urine, Yield and Economics of Groundnut

Article Info

Accepted:

15 November 2019 Available Online: 10 December 2019
A field experiment entitled "Effect of vermicompost, rock phosphate, PSB and different bio-products on yield and economics of groundnut (Arachis hypogea L.)" was conducted at Agronomy Department Farm, College of Agriculture, Dapoli. Dist. Ratnagiri, Maharashtra, India, during rabi seasons 2017-18 and 2018-19. The experiment consisted of eight different organic packages in main plot treatments and three bio-products in sub plot treatments. The experiment was laid out in split plot design with three replications. Data on yield and economics was recorded and statistically analyzed. The experimental results in pooled data revealed that, the groundnut crop grown under $50 \mathrm{~kg} \mathrm{~N}$ through vermicompost $+50 \mathrm{~kg} \mathrm{P}_{2} \mathrm{O}_{5}$ through rock phosphate + phosphate solubilizing bacteria (PSB) $\left(\mathrm{T}_{8}\right)$ were recorded significantly higher dry pod yield $\left(39.99 \mathrm{q} \mathrm{ha}^{-1}\right)$, kernel yield (29.22 q ha ${ }^{-1}$, haulm yield $\left(48.70 \mathrm{~g} \mathrm{ha}^{-1}\right)$ over all other organic packages. In case of economics, the highest net returns of $₹ 75894.94$ ha $^{-1}$ with B: C ratio of 1.44 were obtained

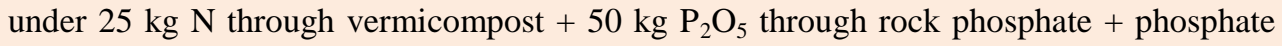
solubilizing bacteria (PSB) $\left(\mathrm{T}_{7}\right)$ followed by $25 \mathrm{~kg} \mathrm{~N}$ through vermicompost $+50 \mathrm{~kg} \mathrm{P}_{2} \mathrm{O}_{5}$ through rock phosphate $\left(\mathrm{T}_{5}\right)$. Application of cow urine $(10 \%)\left(\mathrm{P}_{2}\right)$ were recorded significantly higher dry pod yield (35.69 $\left.\mathrm{q} \mathrm{ha}^{-1}\right)$, kernel yield $\left(25.93 \mathrm{q} \mathrm{ha}^{-1}\right)$, haulm yield $\left(43.25 \mathrm{q} \mathrm{ha}^{-1}\right)$, net returns $\left(58072.35 ₹ \mathrm{ha}^{-1}\right)$ and B: C ratio (1.34) followed by vermi-wash $(3 \%)\left(\mathrm{P}_{3}\right)$ and control $\left(\mathrm{P}_{1}\right)$.

\section{Introduction}

Groundnut (Arachis hypogaea L.) is the important oilseed crop in the India. The crop has its own importance due to high edible oil and nutritional value of kernel as human food and haulm as rich feed for cattle. Its seed contain high quality of $45-50 \%$ edible oil, $25-$ $30 \%$ digestible protein, $20 \%$ carbohydrates, and $5 \%$ fiber and ash which make a sustainable contribution to human nutrition
(Fageria et al., 1997). Groundnut is considered as poor man's almond and also called as "King of oilseeds". It is cultivated in India over 45.97 million ha area with the production of 67.33 million tonnes (both kharif and rabi) and average productivity of $1.47 \mathrm{t} \mathrm{ha}^{-1}$ (Indiastat, 2016). In Maharashtra, groundnut cultivated (both kharif and rabi) over an area of 3.09 million ha with production of 3.34 million tonnes having productivity of $1.08 \mathrm{t}$ $\mathrm{ha}^{-1}$ (Indiastat, 2016). The area under 
groundnut crop in konkan was about more than 15,000 ha with $1,550 \mathrm{~kg} \mathrm{ha}^{-1}$ productivity during 2013-14 (Anonymous, 2013).

Vermicompost contain plant nutrients including $\mathrm{N}, \mathrm{P}, \mathrm{K}, \mathrm{Ca}, \mathrm{Mn}, \mathrm{Zn}$ and $\mathrm{Cu}$ as well as other nutrients the uptake of which has a positive effect on plant nutrition, photosynthesis, the chlorophyll content of the leaves and improves the nutrient content of the different plant component. The soil properties such as $\mathrm{P}^{\mathrm{H}}, \quad$ Ec, available nitrogen, phosphorus, potassium, iron, zinc, copper and manganese were found to improve in the soils treated with vermicompost application (Mathivanan et al., 2013). The nutrients present in vermicompost are readily available to crop plants and produce better plant growth and yield. Vermicompost also contains more number of $\mathrm{N}$-fixing, $\mathrm{P}$-solubilizing and other beneficial microbes, antibiotics, vitamins, hormones, enzymes etc. which have better effects on growth and yield of plants. To overcome the constraints of available phosphorus in acid soil it is imperative to explore all the possible sources of phosphorus nutrient in acid soil. Apart from super phosphate, according to Agarwal et al., (1972), basic slag, rock phosphate and different organic sources are among the different possible sources of phosphorus nutrient in acid soil for plants that have the possibility to play vital role in the future agriculture scenario of our country, simply because, they are cheap, abundantly available in natural way and will be efficient if they are used in scientific way, which has been reviewed by a number of authors. The phosphate solubilizing microorganisms (Pseudomonas) play an important role in conversion of unavailable inorganic $\mathrm{P}(\mathrm{Ca}-\mathrm{P}$, $\mathrm{Fe}-\mathrm{P}$ and Al-P) into available inorganic $\mathrm{P}$ forms through secretion of organic acids and enzymes (Singh, 1999).

Cattle urine has a good manurial value and can be utilized as a bio fertilizer (Khanal et al.,
2011). Cattle urine is a good source of nitrogen, phosphate, potassium, calcium, magnesium, chlorite and sulphate. Application of cow urine has also been reported to correct the micronutrient deficiency, besides improving the soil texture and working as a plant hormone. Vermiwash obtained from dissolution of organic matter by earthworm is also found as a good liquid manure and affect significantly on the growth and productivity of crop during foliar spray, (Subasasri, 2003). It is coelomic fluid extraction contains several enzyme, plant growth stimulating hormones like cytokinins, gibberlines and vitamins along with micro and macro nutrients as nitrogen in the form of mucus, nitrogenous excretory substance, enzyme are present in vermiwash (Tripathi and Bhardwaj, 2004). It also increases the disease resistant power of crop (Yadav et al., 2005). Therefore, keeping these facts in view, an attempt was made to study on the effect of vermicompost, rock phosphate, PSB and different bio-products on yield and economics of groundnut (Arachis hypogea L.).

\section{Materials and Methods}

The field experiment was conducted at Agronomy Farm, College of Agriculture, Dapoli, Dr. Balasaheb Sawant Konkan Krishi Vidyapeeth, Dapoli, Dist. Ratnagiri, Maharashtra State during rabi season of 201718 and $2018-19$ is situated on $17.10^{\circ}$ North latitude and $73.10^{\circ}$ East longitude having elevation of $250 \mathrm{~m}$ above the mean sea level.

The soil of experimental plot was sandy clay loam in texture, moderately acidic in reaction with moderately high in organic carbon content. Soil was medium in available nitrogen $\left(271.86 \mathrm{~kg} \mathrm{ha}^{-1}\right)$, low in available phosphorus (10.55 kg ka-1) and fairly high in available potassium $\left(221.16 \mathrm{~kg} \mathrm{ha}^{-1}\right)$. The main plot treatments comprised of eight organic packages i.e., Control ( $\left.\mathrm{T}_{1}\right)$, RDF (25 $\left.\mathrm{kg} \mathrm{N}+50 \mathrm{~kg} \mathrm{P}_{2} \mathrm{O}_{5}\right)\left(\mathrm{T}_{2}\right), 25 \mathrm{~kg} \mathrm{~N}$ through Vermicompost $\left(\mathrm{T}_{3}\right), \quad 50 \mathrm{~kg} \mathrm{~N}$ through 
Vermicompost $\left(\mathrm{T}_{4}\right), 25 \mathrm{~kg} \quad \mathrm{~N}$ through Vermicompost $+50 \mathrm{~kg} \mathrm{P}_{2} \mathrm{O}_{5}$ through Rock phosphate $\left(\mathrm{T}_{5}\right), \quad 50 \mathrm{~kg} \quad \mathrm{~N}$ through Vermicompost $+50 \mathrm{~kg} \mathrm{P}_{2} \mathrm{O}_{5}$ through Rock phosphate $\left(\mathrm{T}_{6}\right), \quad 25 \quad \mathrm{~kg} \quad \mathrm{~N}$ through Vermicompost $+50 \mathrm{~kg} \mathrm{P}_{2} \mathrm{O}_{5}$ through Rock phosphate + Phosphate solubilizing bacteria (PSB) $\left(\mathrm{T}_{7}\right), 50 \mathrm{~kg} \mathrm{~N}$ through Vermicompost + $50 \mathrm{~kg} \quad \mathrm{P}_{2} \mathrm{O}_{5}$ through Rock phosphate + Phosphate solubilizing bacteria (PSB) $\left(\mathrm{T}_{8}\right.$ )along with sub plot treatments consisted of three bio-products i.e., Control $\left(\mathrm{P}_{1}\right)$, Cow urine $(10 \%)\left(\mathrm{P}_{2}\right)$, Vermi-wash $(3 \%)\left(\mathrm{P}_{3}\right)$. The treatments were replicated thrice under split plot design.

The preparation of field by ploughing once with tractor drawn mould board plough, twice by cultivator which followed by planking. Each operation was followed by planking to have smooth clod free seed bed. After land preparation the layout of all the experiment was marked and sub-plots were demarcated within each main plot. Groundnut seed was sown at the rate of $120 \mathrm{~kg} \mathrm{ha}^{-1}$ with spacing of $30 \mathrm{~cm} \mathrm{X} 15 \mathrm{~cm}$. Application of mannures and fertilizers were given as per the requirement of treatments.

The data on growth and yield attributes were recorded from randomly selected five plants in each plot and dry pod yield, kernel yield and haulm yield recorded from net plot and converted on hectare basis. The experimental data pertaining to each character were analysed statistically by using the technique of Analysis of variance for split plot design and significance was tested by ' $F$ ' test (Panse and Sukhatme, 1967).

\section{Results and Discussion}

\section{Yield of groundnut}

\section{Effect of organic packages}

Pooled data presented in Table 1 indicates that, dry pod yield $\left(\mathrm{q} \mathrm{ha}{ }^{-1}\right)$, kernel yield ( $\mathrm{q}$ $\mathrm{ha}^{-1}$ ) and haulm yield ( $\mathrm{q} \mathrm{ha} \mathrm{h}^{-1}$ ) of groundnut were significantly influenced due to different organic packages. Treatment $50 \mathrm{~kg} \mathrm{~N}$ through vermicompost $+50 \mathrm{~kg} \mathrm{P}_{2} \mathrm{O}_{5}$ through rock phosphate + phosphate solubilizing bacteria (PSB) $\left(\mathrm{T}_{8}\right)$ recorded significantly higher dry pod yield (39.65 $\mathrm{q} \mathrm{ha}^{-1}, 40.34 \mathrm{q} \mathrm{ha}^{-1}$ and 39.99 $\left.\mathrm{q} \mathrm{ha}^{-1}\right)$, kernel yield (28.99 q ha-1, $29.46 \mathrm{q} \mathrm{ha}^{-1}$ and $29.22 \mathrm{q} \mathrm{ha}^{-1}$ ) and haulm yield (48.09 q $\mathrm{ha}^{-1}, 49.32 \mathrm{q} \mathrm{ha}^{-1}$ and $48.70 \mathrm{q} \mathrm{ha}^{-1}$ ) over rest of the treatments during both the years and in the pooled data.

The increase in dry pod yield in the pooled data due to treatments $\mathrm{T}_{8}, \mathrm{~T}_{6}, \mathrm{~T}_{7}$ and $\mathrm{T}_{5}$ over treatment $\mathrm{T}_{1}$, and were to the tune of 87.74 , $82.25,77.93$ and 73.19 per cent, respectively. Similar trend was observed in the kernel yield and haulm yield during both the years of experimentation and in the pooled analysis. These results are in conformity with findings of Zalate et al., (2009), Sarangi and Lama (2013), Chaudhary et al., (2015) and Das et al., (2015)

\section{Effect of bio-products}

Perusal of the data presented in Table 1 revealed that, the different bio-products significantly influenced the dry pod yield (q $\left.\mathrm{ha}^{-1}\right)$, kernel yield $\left(\mathrm{q} \mathrm{ha} \mathrm{h}^{-1}\right.$ ) and haulm yield ( $\mathrm{q}$ $\mathrm{ha}^{-1}$ ) of groundnut during both the years and in pooled data. Application of cow urine (10\%) $\left(\mathrm{P}_{2}\right)$ were recorded significantly higher dry pod yield (35.52 $\mathrm{q} \mathrm{ha}^{-1}, 35.85 \mathrm{q} \mathrm{ha}^{-1}$ and 35.69 $\left.\mathrm{q} \mathrm{ha}^{-1}\right)$, kernel yield $\left(25.76 \mathrm{q} \mathrm{ha}^{-1}, 26.10 \mathrm{q} \mathrm{ha}^{-1}\right.$ and $25.93 \mathrm{q} \mathrm{ha}^{-1}$ ) and haulm yield (43.10 q $\mathrm{ha}^{-1}, 43.39 \mathrm{q} \mathrm{ha}^{-1}$ and $43.25 \mathrm{q} \mathrm{ha}^{-1}$ ) followed by vermi-wash $(3 \%)\left(\mathrm{P}_{3}\right)$ and control $\left(\mathrm{P}_{1}\right)$ in the descending order during both the years of experimentation and in the pooled data. Results of the present investigation corroborate with the findings of Deotale et al., (2008), Patil et al., (2011), Kulkarni et al., (2016) and Sadhukhan et al., (2018). 
Table.1 Effect of different treatments on the yield of groundnut

\begin{tabular}{|c|c|c|c|c|c|c|c|c|c|}
\hline \multirow[t]{2}{*}{ Treatments } & \multicolumn{3}{|c|}{ Dry pod yield (q ha $\left.{ }^{-1}\right)$} & \multicolumn{3}{|c|}{ Kernel yield (q ha $\left.{ }^{-1}\right)$} & \multicolumn{3}{|c|}{ Haulm yield $\left(q\right.$ ha $\left.^{-1}\right)$} \\
\hline & $\begin{array}{c}2017- \\
18\end{array}$ & $\begin{array}{c}2018- \\
19\end{array}$ & Pooled & $\begin{array}{c}2017- \\
18\end{array}$ & $\begin{array}{c}2018- \\
19\end{array}$ & Pooled & $\begin{array}{c}2017- \\
18\end{array}$ & $\begin{array}{c}2018- \\
19\end{array}$ & Pooled \\
\hline \multicolumn{10}{|c|}{ Main plot: Organic package } \\
\hline $\mathbf{T}_{1}$ : Control & 22.28 & 20.33 & 21.30 & 14.56 & 13.25 & 13.91 & 29.25 & 27.01 & 28.13 \\
\hline$T_{2}: \operatorname{RDF}\left(25 \mathrm{~kg} \mathrm{~N}+50 \mathrm{~kg} \mathrm{P}_{2} \mathrm{O}_{5}\right)$ & 32.37 & 33.15 & 32.76 & 22.89 & 23.50 & 23.19 & 38.94 & 39.43 & 39.19 \\
\hline$T_{3}: 25 \mathrm{~kg} \mathrm{~N}$ through Vermicompost & 31.25 & 30.56 & 30.91 & 21.95 & 21.38 & 21.67 & 37.36 & 36.75 & 37.05 \\
\hline$T_{4}: 50 \mathrm{~kg} \mathrm{~N}$ through Vermicompost & 32.88 & 32.98 & 32.93 & 23.36 & 23.32 & 23.34 & 39.31 & 39.37 & 39.34 \\
\hline $\begin{array}{c}\mathrm{T}_{5}: 25 \mathrm{~kg} \mathrm{~N} \text { through Vermicompost }+50 \mathrm{~kg} \mathrm{P}_{2} \mathrm{O}_{5} \\
\text { through Rock phosphate }\end{array}$ & 36.43 & 37.36 & 36.89 & 26.19 & 26.57 & 26.38 & 43.71 & 44.18 & 43.94 \\
\hline $\begin{array}{c}\mathrm{T}_{6}: 50 \mathrm{~kg} \mathrm{~N} \text { through Vermicompost }+50 \mathrm{~kg} \mathrm{P}_{2} \mathrm{O}_{5} \\
\text { through Rock phosphate }\end{array}$ & 38.73 & 38.90 & 38.82 & 27.86 & 28.22 & 28.04 & 46.79 & 46.94 & 46.87 \\
\hline $\begin{array}{c}\mathrm{T}_{7}: 25 \mathrm{~kg} \mathrm{~N} \text { through Vermicompost }+50 \mathrm{~kg} \mathrm{P}_{2} \mathrm{O}_{5} \\
\text { through Rock phosphate }+ \text { Phosphate } \\
\text { solubilizing bacteria (PSB) }\end{array}$ & 37.39 & 38.41 & 37.90 & 26.94 & 27.79 & 27.36 & 44.74 & 45.74 & 45.24 \\
\hline $\begin{array}{c}\mathrm{T}_{8}: 50 \mathrm{~kg} \mathrm{~N} \text { through Vermicompost }+50 \mathrm{~kg} \mathrm{P}_{2} \mathrm{O}_{5} \\
\text { through Rock phosphate }+ \text { Phosphate } \\
\text { solubilizing bacteria }(\mathrm{PSB})\end{array}$ & 39.65 & 40.34 & 39.99 & 28.99 & 29.46 & 29.22 & 48.09 & 49.32 & 48.70 \\
\hline S.Em. \pm & 0.91 & 0.81 & 0.66 & 0.74 & 0.79 & 0.58 & 1.22 & 0.74 & 0.78 \\
\hline C.D. at $5 \%$ & 2.76 & 2.45 & 1.99 & 2.25 & 2.40 & 1.77 & 3.70 & 2.25 & 2.36 \\
\hline \multicolumn{10}{|c|}{ Sub plot: Bio-product } \\
\hline $\mathbf{P}_{1}$ : Control & 32.50 & 32.11 & 32.30 & 22.62 & 22.25 & 22.43 & 39.22 & 38.85 & 39.03 \\
\hline$P_{2}:$ Cow urine $(10 \%)$ & 35.52 & 35.85 & 35.69 & 25.76 & 26.10 & 25.93 & 43.10 & 43.39 & 43.25 \\
\hline$P_{3}:$ Vermi-wash $(3 \%)$ & 33.60 & 34.05 & 33.83 & 23.90 & 24.21 & 24.06 & 40.75 & 41.04 & 40.90 \\
\hline S.Em. \pm & 0.79 & 0.61 & 0.53 & 0.60 & 0.56 & 0.43 & 0.95 & 0.54 & 0.54 \\
\hline C.D. at $5 \%$ & 2.28 & 1.76 & 1.52 & 1.73 & 1.61 & 1.23 & 2.72 & 1.57 & 1.56 \\
\hline \multicolumn{10}{|c|}{ Interaction effect } \\
\hline S.Em.. & 3.42 & 2.69 & 2.31 & 2.62 & 2.50 & 1.90 & 4.16 & 2.42 & 2.43 \\
\hline C.D. at $5 \%$ & NS & NS & NS & NS & NS & NS & NS & NS & NS \\
\hline General mean & 33.87 & 34.00 & 33.94 & 24.09 & 24.19 & 24.14 & 41.02 & 41.09 & 41.06 \\
\hline
\end{tabular}


Table.2 Effect of different treatments on cost of cultivation and gross returns of groundnut

\begin{tabular}{|c|c|c|c|c|c|c|}
\hline \multirow[t]{2}{*}{ Treatments } & \multicolumn{3}{|c|}{ Cost of cultivation $\left(₹ \mathrm{ha}^{-1}\right)$} & \multicolumn{3}{|c|}{ Gross returns (₹ ha ha $^{-1}$} \\
\hline & 2017-18 & 2018-19 & Pooled & 2017-18 & 2018-19 & Pooled \\
\hline \multicolumn{7}{|c|}{ Main plot: Organic package } \\
\hline $\mathrm{T}_{1}$ : Control & 127657.20 & 125548.14 & 126602.67 & 145341.75 & 132687.38 & 139014.56 \\
\hline$T_{2}: \operatorname{RDF}\left(25 \mathrm{~kg} \mathrm{~N}+50 \mathrm{~kg} \mathrm{P}_{2} \mathrm{O}_{5}\right)$ & 134980.89 & 135637.96 & 135309.43 & 168018.87 & 171961.28 & 169990.07 \\
\hline$T_{3}: 25 \mathrm{~kg} \mathrm{~N}$ through Vermicompost & 159417.60 & 158622.81 & 159020.20 & 202703.86 & 198268.45 & 200486.16 \\
\hline$T_{4}: 50 \mathrm{~kg} N$ through Vermicompost & 183380.00 & 183480.06 & 183430.03 & 213278.00 & 213878.41 & 213578.20 \\
\hline $\begin{array}{l}T_{5}: 25 \mathrm{~kg} \mathrm{~N} \text { through Vermicompost }+ \\
50 \mathrm{~kg} \mathrm{P}_{2} \mathrm{O}_{5} \text { through Rock Phosphate }\end{array}$ & 167795.25 & 168774.19 & 168284.72 & 236310.59 & 242175.35 & 239242.97 \\
\hline $\begin{array}{l}\mathrm{T}_{6}: 50 \mathrm{~kg} \mathrm{~N} \text { through Vermicompost }+ \\
50 \mathrm{~kg} \mathrm{P}_{2} \mathrm{O}_{5} \text { through Rock Phosphate }\end{array}$ & 192504.32 & 192685.38 & 192594.85 & 251373.63 & 252459.97 & 251916.80 \\
\hline $\begin{array}{l}\mathrm{T}_{7}: 25 \mathrm{~kg} \mathrm{~N} \text { through Vermicompost }+ \\
50 \mathrm{~kg} \mathrm{P}_{2} \mathrm{O}_{5} \text { through Rock phosphate }+ \\
\text { Phosphate solubilizing bacteria (PSB) }\end{array}$ & 169345.96 & 170441.58 & 169893.77 & 242501.85 & 249075.57 & 245788.71 \\
\hline $\begin{array}{l}\mathrm{T}_{8}: 50 \mathrm{~kg} \mathrm{~N} \text { through Vermicompost }+ \\
50 \mathrm{~kg} \mathrm{P}_{2} \mathrm{O}_{5} \text { through Rock phosphate }+ \\
\text { Phosphate solubilizing bacteria (PSB) }\end{array}$ & 194029.19 & 194789.51 & 194409.35 & 257400.95 & 261962.89 & 259681.92 \\
\hline \multicolumn{7}{|c|}{ Sub plot: Bio-product } \\
\hline$P_{1}$ : Control & 164599.27 & 164181.09 & 164390.18 & 205796.36 & 203283.97 & 204540.17 \\
\hline$P_{2}:$ Cow urine $(10 \%)$ & 167920.76 & 168229.01 & 168074.89 & 225222.49 & 227071.99 & 226147.24 \\
\hline$P_{3}:$ Vermi-wash $(3 \%)$ & 165896.37 & 166332.26 & 166114.31 & 212829.72 & 215570.03 & 214199.87 \\
\hline General mean & 166138.80 & 166247.45 & 166193.13 & 214616.19 & 215308.66 & 214962.42 \\
\hline
\end{tabular}


Table.3 Effect of different treatments on net returns and B: C ratio of groundnut

\begin{tabular}{|c|c|c|c|c|c|c|}
\hline \multirow[t]{2}{*}{ Treatments } & \multicolumn{3}{|c|}{ Net returns $\left(₹\right.$ ha $\left.^{-1}\right)$} & \multicolumn{3}{|c|}{ B: C ratio } \\
\hline & 2017-18 & 2018-19 & Pooled & 2017-18 & 2018-19 & Pooled \\
\hline \multicolumn{7}{|c|}{ Main plot: Organic package } \\
\hline $\mathbf{T}_{1}:$ Control & 17684.55 & 14180.81 & 15932.68 & 1.14 & 1.05 & 1.10 \\
\hline$T_{2}: \operatorname{RDF}\left(25 \mathrm{~kg} \mathrm{~N}+50 \mathrm{~kg} \mathrm{P}_{2} \mathrm{O}_{5}\right)$ & 33037.97 & 36323.32 & 34680.65 & 1.24 & 1.27 & 1.25 \\
\hline$T_{3}: 25 \mathrm{~kg} \mathrm{~N}$ through Vermicompost & 43286.27 & 39645.64 & 41465.95 & 1.27 & 1.25 & 1.26 \\
\hline$T_{4}: 50 \mathrm{~kg} \mathrm{~N}$ through Vermicompost & 30104.91 & 30398.34 & 30251.62 & 1.16 & 1.17 & 1.16 \\
\hline $\begin{array}{l}\mathrm{T}_{5}: 25 \mathrm{~kg} \mathrm{~N} \text { through Vermicompost }+ \\
50 \mathrm{~kg} \mathrm{P}_{2} \mathrm{O}_{5} \text { through Rock Phosphate }\end{array}$ & 68515.33 & 73401.15 & 70958.24 & 1.40 & 1.43 & 1.42 \\
\hline $\begin{array}{l}T_{6}: 50 \mathrm{~kg} \mathrm{~N} \text { through Vermicompost }+ \\
50 \mathrm{~kg} \mathrm{P} \mathrm{P}_{2} \mathrm{O}_{5} \text { through Rock Phosphate }\end{array}$ & 58869.30 & 59774.59 & 59321.95 & 1.30 & 1.31 & 1.31 \\
\hline $\begin{array}{l}\mathrm{T}_{7}: 25 \mathrm{~kg} \mathrm{~N} \text { through Vermicompost }+ \\
50 \mathrm{~kg} \mathrm{P}_{2} \mathrm{O}_{5} \text { through Rock phosphate }+ \\
\text { Phosphate solubilizing bacteria (PSB) }\end{array}$ & 73155.89 & 78633.99 & 75894.94 & 1.43 & 1.46 & 1.44 \\
\hline $\begin{array}{l}\mathrm{T}_{8}: 50 \mathrm{~kg} \mathrm{~N} \text { through Vermicompost }+ \\
50 \mathrm{~kg} \mathrm{P}_{2} \mathrm{O}_{5} \text { through Rock phosphate }+ \\
\text { Phosphate solubilizing bacteria (PSB) }\end{array}$ & 63371.75 & 67173.37 & 65272.56 & 1.33 & 1.34 & 1.33 \\
\hline \multicolumn{7}{|c|}{ Sub plot: Bio-product } \\
\hline $\mathbf{P}_{1}$ : Control & 41274.67 & 41743.46 & 41509.07 & 1.24 & 1.23 & 1.23 \\
\hline$P_{2}:$ Cow urine $(10 \%)$ & 57301.72 & 58842.97 & 58072.35 & 1.33 & 1.34 & 1.34 \\
\hline$P_{3}:$ Vermi-wash $(3 \%)$ & 46933.34 & 49237.77 & 48085.56 & 1.28 & 1.29 & 1.28 \\
\hline General mean & 48503.25 & 49941.40 & 49222.32 & 1.28 & 1.28 & 1.28 \\
\hline
\end{tabular}




\section{Economics of groundnut}

\section{Effect of organic packages}

The study on the economic feasibility of the different organic packages in groundnut revealed that, the maximum gross returns (₹257400.95 ha ${ }^{-1}, \quad ₹ 261962.89$ ha $^{-1}$ and ₹259681.92 $\mathrm{ha}^{-1}$ ) were recorded under $50 \mathrm{~kg}$ $\mathrm{N}$ through vermicompost $+50 \mathrm{~kg} \mathrm{P}_{2} \mathrm{O}_{5}$ through rock phosphate + phosphate solubilizing bacteria (PSB) $\left(\mathrm{T}_{8}\right)$ followed by $\mathrm{T}_{6}, \mathrm{~T}_{7}, \mathrm{~T}_{5}, \mathrm{~T}_{4}, \mathrm{~T}_{2}, \mathrm{~T}_{3}$ and $\mathrm{T}_{1}$ during both the years as well as in the pooled data.

The highest net returns (₹73155.89 $\mathrm{ha}^{-1}$, ₹78633.99 ha $\mathrm{ha}^{-1}$ and ₹75894.94 $\mathrm{ha}^{-1}$ ) and benefit to cost ratio $(1.43,1.46$ and 1.44) were obtained under $25 \mathrm{~kg} \mathrm{~N}$ through vermicompost $+50 \mathrm{~kg} \mathrm{P}_{2} \mathrm{O}_{5}$ through rock phosphate + phosphate solubilizing bacteria (PSB) $\left(\mathrm{T}_{7}\right)$ than remaining treatments during both the years and in the pooled data. These findings are in close conformity with those of Sutaria et al., (2010), Chaudhary et al., (2014), Poonia et al., (2014) and Choudhary et al., (2017).

\section{Effect of bio-products}

In case of economics (Table 2 and 3 ) it was observed that higher cost of cultivation (₹167920.76 ha ${ }^{-1}, \quad ₹ 168229.01$ ha $^{-1}$ and ₹168074.89 $\mathrm{ha}^{-1}$ ), gross return (₹225222.49 $\mathrm{ha}^{-1}$, ₹227071.99 $\mathrm{ha}^{-1}$ and ₹226147.24 $\mathrm{ha}^{-1}$ ), net return (₹57301.72 $\mathrm{ha}^{-1}, ₹ 58842.97 \mathrm{ha}^{-1}$ and ₹58072.35 $\mathrm{ha}_{-1}$ ) and maximum $\mathrm{B}$ : C ratio (1.33, 1.34, 1.34) during 2017-18, 2018-19 and in the pooled data respectively, was recorded under cow urine $(10 \%)\left(\mathrm{P}_{2}\right)$ and it was followed by vermi-wash $(3 \%)\left(\mathrm{P}_{3}\right)$ and control $\left(\mathrm{P}_{1}\right)$, respectively. These findings are in close agreement with Jadhav and Kulkarni (2016), Kulkarni et al., (2016), Shwetha et al., (2018) and Verma et al., (2018).

It may be concluded from the finding of the present study that, to get higher net returns and B: C ratio, groundnut should be grown with $25 \mathrm{~kg} \mathrm{~N}$ through vermicompost $+50 \mathrm{~kg}$ $\mathrm{P}_{2} \mathrm{O}_{5}$ through rock phosphate $+\mathrm{PSB}$ and provided with cow urine (10\%) sprays at 45 , 65 and 85 DAS.

\section{References}

Agarwal, J.P., Yawalkar, K.S. and Bokde, S. (1972). Manures and Fertilizers. AgriHorticultural publishing house. Nagpur, India. P: 9, 110-142.

Anonymous. (2013). Agriculture at a glance. Directorate of Economics and Statistics, Department of Agriculture and Cooperation, Ministry of Agriculture, Government of India, New Delhi.

Chaudhary, J.H. and Sutaliya, R. (2014). Influence of vermicompost, phosphorus and PSB on yield, quality, available nutrients and economics of summer groundnut (Arachis hypogaea L.). Trends In Biosciences.7(24: 4429-4432.

Chaudhary, J.H., Sutaliya, R. and Desai, L.J. (2015). Growth, yield, yield attributes and economics of summer groundnut (Arachis hypogaea L.) as influenced by integrated nutrient management. Journal of Applied and Natural Science. 7(1): 369-372.

Choudhary, K., Sharma, S.R., Jat, R. and Didal, V. (2017). Effect of organic manures and mineral nutrients on quality parameters and economics of sesame (Sesamum indicum L.). Journal of Pharmacognosy and Phytochemistry. 6(3): 263-265.

Das, T., Debnath, P., Satpute, S.B. and Bandyopadhyay, S. (2015). Effect of phosphorus enriched vermicompost on yield of ground nut under irrigated conditions. Indian Journal of Science and Technology. 8(11): 1-11.

Deotale, R.D., Shraddha, R., Kamble, P.S., Sapana, B.B. and Ommala, D.K. (2008). Effect of foliar sprays of vermiwash and cow dung wash on morpho-physiological 
parameters and economics of soybean. $J$. Soils and crops. 18(1): 169-175.

Fageria, N.K., Baligar, V.C. and Jones, C. (1997). Growth and mineral nutrition of field crops 2nd Ed. Marcel Dekker, Inc, New York 1001 k, Pp: 494.

Indiastat, (2016). Seasonwise Area, Production and Productivity of groundnut in India. www.indiastat.com

Jadhav, R.L. and Kulkarni, S. (2016). Effect of foliar spray of nutrients on productivity of green gram (Vigna radiate L.) in North Eastern transitional zone of Karnataka, India. Legume. Res.39(5): 817-817.

Khanal, A., Shakya S. M., Shah, S. C. and Sharma, M. D. (2010). Utilization of urine waste to produce quality cauliflower. The Journal of Agriculture and Environment. 12: 84-90.

Kulkarni, S., Upperi, S.N. and Jadhav, R.L. (2016). Greengram productivity enhancement through foliar spray of nutrients. Legume Research. 39(5): 814816.

Mathivanan, S., Kalaikandhan, R., Chidambaram, AL. A. and Sundramoorthy, P. (2013). Effect of vermicompost on the growth and nutrient status in groundnut (Arachis hypogaea. L). Asian J. Plant Sci. Res. 3(2): 15-22.

Panse, V.G. and Sukhatme, P.V. (1967), Statistical methods for Agricultural workers, I.C.A.R., New Delhi.

Patil, S.V., Halikatti, S.I., Sreenivasa, M.N. and Babalad, H.B. (2011). Influence of organic amendments on soil enzyme activities, yield, yield attributes and economics of chickpea (Cicer arietinum L.) grown in vertisol. Advance Research Journal of Crop Improvement.2(2): 235240.

Poonia, T.C., Raj, A.D. and Pithia, M.S. (2014). Effect of organic, inorganic and biofertilizers on productivity and economics of groundnut-pigeonpea relay intercropping system in vertisols of Gujarat. Journal of Experimental Biology and Agricultural Sciences. 2(6): 560-566.

Sadhukhan, R., Bohra, J.S. and Choudhury, S. (2018). Effect of fertility levels and cow urine foliar spray on growth and yield of Wheat (Triticum aestivum L.). Int. J. Curr. Microbiol.App. Sci. 7(3): 907-912.

Sarangi, S.K. and Lama, T.D. (2013). Composting rice straw using earthworm (eudrilus eugeniae) / fungal inoculants (Trichoderma viridae) and its utilization in rice (Oryza sativa L.) Groundnut (Arachis hypogaea L.) cropping system. Indian J. Agron., 58(2): 146-151.

Shwetha, B.N., Anupama, C., Sowmya, T.M. and Yaligar, R. (2018). Effect of foliar nutrition on productivity of groundnut crop. Journal of PharmacognosyandPhytochemistry.SP1: 2357-2360.

Singh, M.V. (1999). Sulphur management for oilseed and pulse crops. Indian Institutes of Soil Science (Bhopal) Bulletin No. 3. pp 2-5.

Subasashri, M. (2003). Vermiwash collection and its pesticidal properties. The Hindu. 17: 1-2.

Sutaria, G.S., Akbari, K.N., Vora, V.D., Hirpara, D.S. and Padmani, D.R. (2010). Response of legume crops to enriched compost and vermicompost on vertic ustchrept under rainfed agriculture. Legume Research. 33(2): 128-130.

Tripathi, G. and Bharadwaj, P. (2004). Comparative studies on biomass production, life cycles and composting efficiency of Eisenia foetida (Savigny) and Lampito mauritii (Kingberg). Bioresearch Technology. 92: 275-278.

Verma, S., Singh, A., Pradhan, S.S., Singh, J.P. and Verma, S.K. (2018). Effects of organic formulations and synthetic fertilizer on the performance of 
pigeonpea in eastern region of Uttar Pradesh. Bangladesh J. Bot. 47(3): 467471.

Yadav, A.K., Kumar, K., Singh, S. and Sharma, M. (2005). Vermiwash- A liquid bio-fertilizer, Uttar Pradesh. Journal of Zoology. 25(1): 97-99.
Zalate, P.Y. and Padmani, D.R. (2009). Effect of organic manure with and without biofertilizers on growth, nodulation and yield of groundnut (Arachis hypogaea L.). International Journal of Agricultural Sciences. 5(2): 343-345.

\section{How to cite this article:}

Ashwini R. Chavan, S. A. Chavan, Aparna M. Yadav and Chavan, V. G. 2019. Effect of Vermicompost, Rock Phosphate, PSB and Different Bio-products on Yield and Economics of Groundnut (Arachis hypogea L.). Int.J.Curr.Microbiol.App.Sci. 8(12): 2031-2039. doi: https://doi.org/10.20546/ijcmas.2019.812.240 